\title{
Anna Boguska
}

Instytut Slawistyki

Polska Akademia Nauk

\section{Przemiany utopii w chorwackiej prozie insularnej drugiej połowy XX i początku XXI wieku na wybranych przykładach}

\section{W stronę regionalizmu}

W refleksji polskich slawistów na temat chorwackiej literatury w ciągu ostatnich dwudziestu lat powracają z zadziwiającym niekiedy uporem problemy tradycji narodowej kraju i jej porządkowania, patriotyzmu oraz postkomunizmu, kwestie tożsamościowe czy zagadnienia związane z emigracją. Czołowymi bohaterami prac stają się m.in. autorzy tłumaczonych na język polski tekstów, często kontrowersyjni w samej Chorwacji, jak np. Dubravka Ugrešić, Daša Drndić oraz Slavenka Drakulić - a zatem literatki, które umieszcza się we wspólnej szufladzie oznaczonej tabliczką „uchodźstwo” oraz „žensko pismo" - czy Miljenko Jergović, funkcjonujący, jak zaznacza np. Leszek Małczak (2005a), jako ponowoczesny apatryda, manifestujący własną pluralistyczną

This is an Open Access article distributed under the terms of the Creative Commons Attribution 3.0 PL License (creativecommons.org/licenses/by/3.0/pl/), which permits redistribution, commercial and non-commercial, provided that the article is properly cited. () The Author(s) 2014. 
tożsamość niejako wbrew nowoczesnym tendencjom dominującym w Chorwacji, zwłaszcza w latach dziewięćdziesiątych ubiegłego stulecia ${ }^{1}$. Jeśli tematem wywoławczym czyni się kategorie inne niż wskazane, np. podmiotowość, to najczęściej w kontekście doświadczeń wojennych ${ }^{2}$. Teksty niewpisujące się we wskazaną problematykę, choćby wydane w ciągu ostatnich dwudziestu lat (np. prace Damira Miloša, Zvonimira Majdaka, Gorana Tribusona, Petra Šegedina, Ranka Marinkovicia, Slobodana Novaka, Pera Budaka, Ivana Lovrenovicia, Dalibora Cvitana czy Senka Karuzy) komentuje się nader rzadko albo w ogóle. Krótko mówiąc, myśli polskich badaczy zaprzątają najczęściej sprawy oscylujące wokół spraw aktualnych, życia społeczno-politycznego, których ważność pozostaje wprawdzie bezdyskusyjna, zwłaszcza gdy mowa o tak traumatycznym doświadczeniu, jak wojna, ale przez które chorwacka scena literacka może jawić się polskiemu odbiorcy jako „dziecko kulturalnej paranoi”, żeby użyć określenia Punisy Perišića (Dąbrowska-Partyka, 2005, s. 214), przestrzeń zaprzątnięta nade wszystko chorwackością, niejako zamknięta na bodźce zewnętrzne i włączająca się tylko niekiedy w ponadnarodowe, uniwersalne dyskusje w obszarze estetyki i kultury jako takiej ${ }^{3}$. Tymczasem nic bardziej mylnego.

Interesującą i odmienną perspektywę oglądu chorwackiej literatury, w którą wpisuje się niniejsze opracowanie, proponuje wspomniany już Leszek Małczak w artykule zatytułowanym Przestrzenne konteksty chorwackiego literaturoznawstwa. Badacz wysuwa tam na pierwszy plan kategorię terytorializmu czy regionalizmu, stanowiącą naturalną konsekwencję policentryczności przestrzeni kulturowej Chorwatów (Małczak, 2005b, s. 48). Śledząc koleje losu zjawiska w okresie poiliryjskim, czyli w czasie, kiedy polityczna, gospodarcza i kulturalna przestrzeń Chorwacji podporządkowane zostały jednemu, zagrzebskiemu centrum, odnotowuje on aktualność tożsamości regionalnej mieszkańców poszczególnych obszarów i konstatuje, że istota chorwackości

1 Przykłady prac, w których podejmuje się zasygnalizowaną tematykę, to m.in.: Dąbrowska-Partyka, 2005; Dyras, 1999, 2002, 2009; Jawoszek, 2009; Kornhauser, 1999, 2005; Małczak, 2005a; Wołek-San Sebastian, 2009.

${ }^{2}$ Problematykę podmiotowości zderzonej ze złem wojennym podejmuje m.in. Barbara Czapik-Lityńska (2005) na przykładzie wybranych utworów Slavenki Drakulić, Dubravki Ugrešić oraz Dubravki Oraić Tolić. Natomiast Krystyna Pieniążek-Marković (2005) omawia rozpad podmiotu doświadczonego przez wojnę w oparciu o postmodernistyczną poezję pokolenia „Quorumowców”.

${ }^{3}$ Jako przykłady prac podejmujących kwestie ponadnarodowe i uniwersalne wskazać można m.in.: Kornhauser, 2001, 2003; Małczak, 2004; Pieniążek-Marković, 2011. 
wciąż sprowadza się do troistości, do współegzystowania komponent śródziemnomorskiej, środkowoeuropejskiej i bałkańskiej. Nasilenie się refleksji na temat literatury kraju zorientowanej regionalistycznie przypada, jak zaznacza badacz, na koniec lat dziewięćdziesiątych ubiegłego wieku, co inspirowane jest dyskursem poststrukturalistycznym, postkolonialnym oraz doraźnymi interesami politycznymi (Małczak, 2005b, s. 52). W opinii Vinka Brešicia (Brešić, 2005), autora prac poświęconych m.in. Slawonii i slawońskości, którą przeciwstawia on śródziemnomorskości, tendencja ta mogła objawić się dopiero wtedy, kiedy Chorwacja wyszła z Jugosławii, zmieniły się ogólne paradygmaty kulturowe i perspektywa regionalistyczna przestała być postrzegana jako partykularyzm, $\mathrm{tj}$. atak na politycznie delikatny status chorwackiej kultury wewnątrz państwa związkowego. Wspomniany historyk literatury interpretuje rozkwit regionalizmu także jako reakcję na zaostrzający się proces globalizacji oraz jako chorwacką odpowiedź na konsumencką, zuniwersalizowaną kulturę, odrzucającą dorobek przeszłości. Jakby nie odczytywać tego faktu, znamienne jest, że przyjęcie zarysowanej tu perspektywy oglądu literatury, odwraca wzrok badacza od najczęściej komentowanych kwestii społeczno-politycznych ${ }^{4}$ i ukierunkowuje go na sprawę estetyki czy estetyk twórczości przedstawicieli poszczególnych regionów. Taką perspektywę badawczą przyjmowali, jak wskazuje Vinko Brešić, rozmaici Chorwaci.

I tak na przykład Zvonimir Mrkonjić, operując podziałem na część kontynentalną i śródziemnomorską, tę pierwszą zwykł określać jako narracyjną, tę drugą zaś - jako medytacyjną. Vladimir Vratović śródziemnomorską komponentę dostrzegł w połączeniu elementów antycznych, chrześcijańsko-łacińskich, klasyczno-humanistycznych i włoskich, a Tomislav Ladan, który choć podawał w wątpliwość istnienie odrębnego, spójnego modelu literatury śródziemnomorskiej, zauważył cechującą ją skłonność do mitologii, syntetyczności i muzealizacji dziedzictwa (Brešić, 2004, s. 81-82). Komponentę kontynentalną, środkowoeuropejską czy slawońską, charakteryzowałyby z kolei ukierunkowanie na ziemię i geograficzno-geologiczne szczegóły krajo-

${ }^{4}$ Dean Duda zauważa, że zmęczenie tematyką narodową w odniesieniu do literatury dało się odczuć w samej Chorwacji u progu XXI wieku, kiedy to na wiosnę roku 2000 powstał FAK - Festiwal Literatury Alternatywnej (Festival alternativne književnosti), przemianowany z czasem na Festiwal Literatury A (Festival A književnosti). Inicjatorzy FAK-u byli skłonni włączyć do swojego przedsięwzięcia tylko tych, którzy m.in. „nie psuli chorwackiej przestrzeni publicznej ksenofobicznymi poglądami” lub „wyrazili swój sprzeciw wobec dominującej wyłączności i kiczu nacjonalistycznej koncepcji kultury” (Duda, 2005, s. 231). 
brazu (Vinko Brešić), eksponowanie moralnego rozpasania (Tin Ujević, Tomo Matić), niegospodarności lokalnych gospodarzy, a także złego wpływu obcych i inteligencji (Antun Barac).

Najpełniejszy obraz regionalnego zróżnicowania chorwackiej literatury dał jak dotychczas Pavao Pavličić (2004), który w artykule zatytułowanym Hrvatska književnost sjevera i juga (Chorwacka literatura Północy i Południa) stwierdził, że Północ kraju skoncentrowana jest na świecie materialnym, w związku z czym teksty przedstawicieli tego obszaru obfitują w szczegółowe opisy lasów, rzek, piwnic i strychów, przepełnione są zapachem chleba, wonią ryb i smakiem papryki, pomija się w nich zaś relacje międzyludzkie, które z kolei stanowią główny obszar zainteresowania reprezentantów Południa, obojętnych niejako na materialność i przedmiotowośćc ${ }^{5}$ Zdaniem chorwackiego badacza literatura śródziemnomorska wpisuje się w platoński światopogląd i ukierunkowana jest na to, co wykracza poza doczesność - na świat idei. Z kolei twórczość kontynentalna, $\mathrm{z}$ ducha arystotelejska, skoncentrowana jest na bycie ziemskim, jego pilnej obserwacji i realistycznym opisie (Pavličić, 2004, s. 116-117). Konsekwencją tego pozostaje w moim odczuciu fakt, że literatura chorwackiego Południa, bardziej otwarta na problematykę ogólnoludzką, jest skłonniejsza do eksperymentu i że to w jej obrębie szukać należy przejawów nowych tendencji światopoglądowych i artystycznych ${ }^{6}$. Wpisująca się w ten obszar chorwacka proza insularna XX i XXI wieku - dorobek, jak zaznacza Krešimir Nemec (2006), kilkunastu współczesnych pisarzy, m.in. Petra Šegedina, Slobodana Novaka, Ranka Marinkovicia, Branka Belana, Antuna Šoljana, Zorana Fericia, Damira Miloša, Renata Bareticia, Senka Karuzy ${ }^{7}$ - wydaje się

${ }^{5}$ We wspomnianym artykule Leszek Małczak (2005b), sympatyzujący z zarysowaną przez Pavličicia wizją (polski badacz nie odnosi się do przytoczonego tutaj tekstu Pavličicia, lecz do pracy zatytułowanej Južno od sjevera, sjeverno od juga), choć świadomy jej upraszczającego charakteru, w moim przekonaniu słusznie upomina się o uzupełnienie jej o komponent bałkański (czy bośniacko-hercegowiński, jak go dokładnie nazywa). Podążając za myślą Juliana Kornhausera, wskazuje, że dla tego modelu kluczowe są: „świadomość wielokulturowości, wielowyznaniowości i wieloetniczności, poczucie mentalnej inności, światopoglądowo zdefiniowany wschodni fatalizm i tożsamość pogranicza” (Małczak, 2005b, s. 56).

${ }^{6}$ Uznaję, że rozpoznanie to jest zasadne, gdy rozważa się literatury poszczególnych regionów jako całość. Bez wątpienia innowacyjność i eksperyment można odnaleźć również u wybranych przedstawicieli Północy (np. u Miroslava Krležy), niemniej jednak jest to rzadsza aniżeli u pisarzy z Południa cecha ich twórczości.

7 Termin „proza insularna” (inzularna proza) wprowadził w 2006 roku Krešimir Nemec (2006) na określenie pewnej grupy tekstów literackich, które uznaje za odrębne zjawisko 
idealną mikroprzestrzenią do obserwacji zjawisk uniwersalnych, które w europejskiej czy zachodniej makroprzestrzeni mogą być nieco słabiej zauważalne. A ponieważ problematyka wyspiarskości niejako naturalnie oscyluje wokół tematu utopii, ona będzie przedmiotem rozważań w niniejszej pracy.

\section{Trzy oblicza utopii}

Myślenie utopijne Zachodu przynajmniej od czasów klasycznego tekstu Tomasza Morusa - a jak wskazuje John Gillis, autor książki Islands of mind, także znacznie wcześniej, bo już w starożytności - ciążyło ku wyspie jako przestrzeni przynależącej do „innego" świata, przestrzeni mitycznej, której ludzkość z chęcią przypisywała sensotwórczą moc i gdzie najchętniej lokowano początkowo sferę sacrum, a z czasem - marzenia o lepszym świecie (Gillis, 2004, s. 30-31). Nie dziwi zatem, że w literaturze kraju, który szczyci się posiadaniem największej na świecie liczby wysp, podejmowana jest tematyka wyspiarskości i że twórczość ta dotyka kwestii niewystarczalności człowieczego hic et nunc oraz jest przejawem marzeń o przekroczeniu własnej kondycji, czego wyrazy widać w rozmaitych upostaciowaniach ideału ludzkiego życia. Przypadłość tę Bogdan Banasik określa jako typowy dla Zachodu optymizm, zastanawiając się jednak, czy jest on inspiracją do konstruowania lepszej przyszłości czy oznaką wszechobecnej woli samoułudy wyrosłej z ressentiment (Banasik, 2010, s. 42). Pytanie to, które badacz pozostawia bez odpowiedzi, przyświecać mi będzie w refleksji nad trzema wybranymi tekstami Chorwatów - Izgubljeni zavičaj (Utracona ojczyzna, 1954) Slobodana Novaka, Otok snova (Wyspa snów, 1996) Damira Miloša i Vodič po otoku (Przewodnik po wyspie, 2005) Senka Karuzy - które postrzegam jako reprezentacje utopii kolejno modernistycznej, postmodernistycznej i postpostmodernistycznej.

Poszukując najlepszej definicji utopii, Leszek Kleszcz sięga po encyklopedię Trzaski, Everta i Michalskiego, następnie słownik Władysława Kopalińskiego oraz Wielką Encyklopedię Powszechną, by w końcu powrócić do źródła, do

w korpusie chorwackich prac o charakterze artystycznym. Jak zaznacza badacz, chodzi o ten fragment literackiej produkcji, w którym podejmuje się specyficzną problematykę insularności, śródziemnomorskiego pejzażu i kultury, pewną szczególną filologię morza, jak zwykł o niej mawiać Claudio Magris. Wyspa zarysowywana na kartach tych tekstów stanowi autarkiczny mikrokosmos, uniwersum samo dla siebie, gdzie egzystencjalne problemy i ludzkie dramaty przybierają szczególnie ostre kontury. 
autora nazwy, Thomasa More’a, i powtórzyć historię o „dobrym-nie-istniejącym miejscu” (Kleszcz, 1997, s. 9-10). Serbski badacz Nikola Dedić, autor pracy Utopijski prostori umetnosti i teorije posle 1960, również odwołuje się do idei Anglika, którą uzupełnia komentarzem Branislava Dimitrijevicia, że to:

„mesto bez mesta, u njemu se vidimo tamo gde nismo, u marginarnom prostoru koji se otvara, potencjialno, s one strane svoje površine, u njemu se nalazimo tamo gde nas nema, i što je još važnije, vidimo se tamo gde ne postojimo" (Dedić, 2009, s. 17) ${ }^{8}$.

Śledząc przemiany utopii, Dedić zauważa, że w klasycznym renesansowym modelu była ona projekcją idealnego miasta, matrycą skonstruowaną $\mathrm{w}$ ten sposób, by włączać ludzi w harmonię uniwersum, w stabilną i niezmienną hierarchię, podczas gdy w czasach nowoczesnych, tj. wraz z pojawieniem się oświeceniowego racjonalizmu, a nieco później - romantyzmu, pierwotnie przestrzenna wizja zamieniona została przez utopię rozumianą jako metafora czasowa (Dedić, 2009, s. 193). Elementy obu porządków odnaleźć można w powieści Slobodana Novaka Izgubljeni zavičaj, w której narrator powraca w myślach do przeszłości, na bezimienną Wyspę, gdzie się wychowywał? W czterech kolejnych rozdziałach opowiadacz przedstawia ją niczym idylliczną krainę dzieciństwa, przypominającą Wergiliuszową Arkadię, wyposażoną w niezbędne rekwizyty, jakie tradycja wpisała w topos krainy idealnej: pejzaż przybierający kształt ogrodu, przyrodę w stanie dzikim, doskonale jednak zaopatrzoną we wszelkie dobra - drzewo, dające cień, źródło z wyśmienitą wodą, umiarkowany klimat i lekki wietrzyk, który chłodzi - oraz wiosnę jako ulubioną porę roku i poranek jako ulubioną porę dnia (Curtius, 2005, s. 202). Zarysowany tutaj krajobraz zaludnia w książce Novaka swoista grupa postaci, tworzących własny społeczny, uporządkowany mikrokosmos i są to, jak nakazuje pierwowzór, opisany choćby przez Ernsta Roberta Curtiusa, pasterze owiec. Czytelnik zanurza się w świecie „łagodnego” prymitywizmu, który

8 „Miejsce bez miejsca, w nim widzimy się tam, gdzie nie jesteśmy, w marginesowej przestrzeni, która się otwiera, potencjalnie, z tamtej strony swojej powierzchni, w nim znajdujemy się tam, gdzie nas nie ma, i, co jeszcze ważniejsze, widzimy się tam, gdzie nie istniejemy“. Tłumaczenie moje - A.B.

${ }^{9}$ W niniejszym artykule ograniczam się do skrótowego przedstawienia trzech utopijnych wizji, jakie zostały zamknięte w literackich obrazach wybranych przeze mnie pisarzy - pomijam przy tym cały kontekst, który w sposób bezpośredni nie wiąże się z omawianą problematyką. Na temat twórczości Senka Karuzy szerzej pisałam w osobnych omówieniach: Boguska, 2009, 2011, 2012. Pozostałe prace obszerniej omawiam w rozprawie doktorskiej, która jest przygotowywana do druku. 
Erwin Panofsky w tekście Et in Arcadia ego opisuje jako „złoty wiek obfitości, niewinności i szczęścia” - innymi słowy - „jako życie cywilizowane, oczyszczone z przywar" (Panofsky, 1971, s. 325). Ewokacja Novaka, poprzez którą wyraża on nieprzemijającą tęsknotę za doskonałością - tęsknotę taką, jaką ją widział Antoni Lange, czyli bolesną i niebezpieczną dla duchowej kondycji człowieka (Wojciechowski, 2007, s. 105), jest powrotem do momentu źródłowego ludzkości, co z kolei Bogdan Banasik uznaje za tendencję wrodzoną: „Skoro człowiek z Arkadii się wywodzi - pisze filozof - to w naturalny sposób za «dzieciństwem» tęskni i aspiruje do odzyskania niegdysiejszej świetności" (Banasik, 2010, s. 27). Jego zdaniem korelatem perspektywy źródłowości, wiązanej ze szczęściem, błogostanem, harmonią, bezkonfliktowością, bezproblemowością, sprawiedliwością, równością, dobrobytem i jawiącej się w kategoriach matczynego łona, arkadyjskiej kolebki ludzkości czy wieku naturalnej niewinności, jest w płaszczyźnie jednostkowej literacka „mitologia dzieciństwa”. Tak jednak jak w Wergiliuszowej Arkadii nie brakowało tragedii, o czym przypomina Erwin Panofsky, śledząc historię rozumienia, znajdującej się na obrazie Joshui Reynoldsa inskrypcji, która brzmiała: „Et in Arcadia ego” („Ja jestem nawet w Arkadii”) i którą wypowiadać miała Śmierć, tak też nie może jej zabraknąć w krainie odmalowanej przez Novaka. Skrzętnie budowana w czterech kolejnych partiach tekstu wizja naturalnej szczęśliwości niewielkiej wyspiarskiej wspólnoty, wyobrażona poprzez opis prac rolniczych typowych dla każdej z pór roku, jakie ta garstka ludzi wykonuje, zanegowana zostaje w części piątej, finalnej, gdzie autor zarzuca naiwną i idealizującą dziecięcą, perspektywę i wprowadza na pierwszy plan dojrzały, rozczarowany życiem podmiot, który przybywając na Wyspę dostrzega tylko resztki i zgliszcza owiane funeralną atmosferą ${ }^{10}$ :

„Soba je bila groblje nekadašnjeg interijera u kome se zbivalo moje djetinstvo. Od svakog para pokućstva po jedan osamljeni komad. Od svake sobe po nekoliko rasturenih dijelova. Predmeti, koji su imali upotrebu i život u našoj kući, ležali su

${ }^{10}$ Leszek Kleszcz (1997), omawiając różne typy utopii, przypomina m.in. podział Lewisa Mumforda na utopie ucieczki i rekonstrukcji. Te pierwsze, do których zaliczyć można wizję Novaka, pozwalają uwolnić się od trudności i frustracji, są rodzajem azylu. Z kolei Jerzy Szacki (2000), jak zaznacza badacz, sięga po pojęcie utopii eskapistycznych, określając tym mianem marzenia o lepszym świecie, które nie pociągają za sobą nakazu walki o niego. Obraz Novaka byłby w tym podziale utopią eskapistyczną czasu (uchronią), która ukazuje szczęśliwe „kiedyś”. Więcej na temat uchronii we współczesnej literaturze zob. Wesseling (1997, s. 203-211); Kleszcz (1997, s. 29). 
ovdje izloženi kao relikvije i namješteni. Mrtvi. A drugi opet poniženi slučajnom i banalnom svrhom" (Novak, 1969, s. 76) ${ }^{11}$.

Jakże bliska to aura tej znanej z tekstów słynnego europejskiego melancholika, Waltera Benjamina: „Zwrócił oblicze ku przeszłości. Gdzie nam ukazuje się łańcuch zdarzeń, on widzi jedną wieczną katastrofę, która nieustannie piętrzy ruiny na ruinach i ciska mu pod stopy. Chciałby zatrzymać się, zbudzić zmarłych i złączyć to, co rozbite" (Benjamin, 1996, s. 418). W tekście Chorwata spełnia się przekonanie Zygmunta Baumana, który twierdzi, że najwybitniejsi potomkowie nowoczesności dają wyraz swej synowskiej wierności nie inaczej niż stając się jej grabarzami, że są genetycznie zdeterminowani do roli jej krytyków, a ostatecznie - plutonu egzekucyjnego. "Musieli prędzej czy później odmówić zaufania idei bezpiecznych przystani” (Bauman, 2013a, s. 134) - podsumowuje ich los socjolog i dodaje, że nowoczesność buduje taki układ, w którym kultura służyć może rzeczywistości nie inaczej niż przez jej podkopywanie, co nadaje jej rys tragiczny i skazuje na bycie zadomowioną $\mathrm{w}$ swej bezdomności. Ta ostatnia jest również przeznaczeniem bohatera powieści, albowiem odmalowana przez niego sielska kraina traci ostrość konturów w końcowych partiach tekstu, gdzie zostaje sprowadzona do roli nostalgicznego przywidzenia ${ }^{12}$. Świadomość tego faktu prowadzi do dramatycznego wyznania bohatera - „Sada, kad brod ulazi u luku, treba priznati barem, da je Otok nekada bio moj zavičaj, i da to znaju i ljudi koji su ovdje zavičajni. Ali zavičaja zapravo nemam i ne znam da li mi je danas i potreban" (Novak, 1969, s. 73) ${ }^{13}$ - za sprawą którego można w nim

11 „Pokój stanowił jakby cmentarzysko wnętrza, w którym upłynęło moje dzieciństwo. Z każdej pary sprzętów - jedna samotna sztuka. Z każdego pokoju - kilka osobnych cząstek. Przedmioty, które w naszym domu miały swoje zastosowanie i życie, tu leżały wystawione jak relikwie i uporządkowane. Martwe. A inne znów poniżone przypadkowym i banalnym przeznaczeniem" (Novak, 1990, s. 80).

12 Bliskość utopii i nostalgii (oraz utopii i antyutopii/dystopii oraz heterotopii) akcentuje Nikola Dedić (2009). Nostalgia to, jak podaje badacz, żal z powodu niemożliwości mitycznego powrotu, utraty pewnego zaczarowanego świata, który miał jasne granice i wartości lub wyraz duchowej tęsknoty, nostalgia za absolutem, za domem, który jest zarazem fizyczny i duchowy, za rajską jednością czasu i przestrzeni, które poprzedzały wejście w Historię. Wydaje się, że ten stan ducha bliski jest jednostce nowoczesnej, która choć z nadzieją na osiedlenie wyrusza w drogę, stale pozostaje wędrowcem z musu (Dedić, 2009, s. 25-26).

13 „Teraz, gdy statek wchodzi do portu, trzeba przynajmniej przyznać, że tu, na Wyspie, były kiedyś moje strony rodzinne i tutejsi ludzie o tym wiedzą. Lecz ja w gruncie rzeczy stron rodzinnych nie mam i nawet nie wiem, czy są mi dziś potrzebne” (Novak, 1990, s. 76). 
zobaczyć Baumanowskiego nowoczesnego wędrowca, charakteryzującego się nade wszystko nieprzynależnością niebędącą wynikiem wyboru.

W artykule Postmodernizm - zmierzch czy afirmacja utopii? Michał Mokrzan zauważa, że koniec nowoczesności utożsamiono z końcem utopii (Mokrzan, 2006, s. 67). Tymczasem Zygmunt Bauman twierdzi, iż nadal jesteśmy nowocześni w najbardziej nowoczesnym z sensów: „w sensie nadziei, że można uczynić rzeczy innymi niż są, i że należy to zrobić, bowiem rzeczy nie są tak dobre, jak powinny być i jak być by mogły" (Bauman, 2013a, s. 138). Jego zdaniem wciąż pragniemy, aby zadanie zostało wykonane, przekonaliśmy się co najwyżej o bezużyteczności narzędzi, które wykorzystywano, i dlatego też aktualnie szukamy nowych, lepszych. Pogląd ten wydaje się bliski Mokrzanowi, który w swym tekście nie tylko go przywołuje, ale też uznaje za wątpliwą tezę Fernando Ainsy, jakoby postmodernizm kategorycznie negował idealne wizje przyszłości, czyniąc ją tak przedmiotem krytycznej refleksji. Wśród przeciwników końca utopii wymienia on Jürgena Habermasa i Wolfganga Welscha. Obaj nie godzą się na ogłoszenie kresu utopii jako takiej, uznając co najwyżej zmierzch określonych jej form ${ }^{14}$. Co więcej, Mokrzan wykazuje, że czołowi twórcy filozoficznego postmodernizmu - Jean-Francois Lyotard i Richard Rorty - sami są autorami projektów utopijnych: pierwszy - utopijnego obrazu ponowoczesnego społeczeństwa opartego na postulacie równoprawności wszystkich dyskursów, drugi zaś - utopijnej wizji postmodernistycznego liberalizmu mieszczańskiego. „Nie nastąpił żaden koniec utopii - konstatuje badacz - pomimo niechęci do totalizujących utopii nowoczesności, których zamiarem było wprowadzenie ujednoliconego obrazu rzeczywistości. [...] Zmienił się natomiast sposób, w jaki myślenie utopijne się objawia, jakie sobie stawia cele i jak chce je osiągnąć” (Mokrzan, 2006, s. 77).

Mniemanie to wydaje się przynajmniej częściowo zasadne także w kontekście powieści Damira Miloša o znaczącym tytule Otok snova. Jej tematykę najłatwiej streścić, jeżeli sięgnie się po opisany przez Hannę Gosk schemat zmian, jakim podlegała polska utopia socrealistyczna, w której początkowo prezentowano wizję idealnego społeczeństwa (odsłona pierwsza), by następnie ukazać ją w wersji doprowadzonej do absurdu (odsłona druga). W kolejnych

14 Jean Baudrillard mówi o końcu utopii, ponieważ, jak zaznacza Mokrzan, widzi on ponowoczesność jako utopię zrealizowaną. Według niego „niebo utopii” zstąpiło na ziemię i to, co niegdyś jawiło się jako świetlana perspektywa, aktualnie odczytywane jest jako katastrofa (Mokrzan, 2006, s. 69-70). 
etapach dochodziło do przekształcenia obrazu w jego własne ideologiczne przeciwieństwo (odsłona trzecia) i w końcu - poddania go dyskursywizacji, odsłonięcia mechanizmów jego własnej struktury i przemiany w Baudrillardowskie symulakrum, objawiające się w nieograniczonej liczbie kopii nieposiadających oryginału (odsłona czwarta) (Gosk, 2007, s. 139). U Miloša wizję beztroskiego wakacyjnego podróżowania młodych turystów wśród malowniczych wysp chorwackiego wybrzeża, inicjującą powieściową akcję, szybko zastępuje jej zdeformowana wersja, w ramach której czytelnik wprawdzie dalej śledzi wyprawy bohaterów na tytułową Wyspę Snów, lecz już tylko te, które odbywają oni we śnie (odsłona pierwsza i druga). Tym samym obnażony zostaje absurdalny charakter idyllicznej rzeczywistości, co można potraktować jako pierwszy, jeszcze dość niewyraźny sygnał chęci zdegradowania pierwotnie sielskiego obrazu oraz znak, że tytułowe miejsce nosi imię dosłowne, że to przestrzeń, w której tylko się śni. W odniesieniu do dalszych partii tekstu można już mówić o wyraźnym przejściu idylli w piekło, albowiem bohaterka książki, a wraz z nią także czytelnik ${ }^{15}$, dowiadują się, że ci, którzy śnią własne marzenia, z czasem obdarowywani są już tylko obrazami pozbawionego wszelkiej cudowności, codziennego, szarego życia, z którego pragnęli uciec, za co dobrowolnie płacą skrzętnie odkrawanymi skrawkami własnego ciała, a tym samym doprowadzają je do całkowitej degradacji (odsłona trzecia). Czwarta i ostatnia odsłona - objawienie symulacyjnego charakteru rzeczywistości - ujawniona zostaje wraz $\mathrm{z}$ informacją, że zaprezentowana na kartach powieści historia jest tylko treścią książki, jaką tworzy jeden $z$ dwojga głównych bohaterów omawianego tekstu, któremu właściciele tytułowej wyspy, także bohaterowie snu, zlecają przejęcie roli pisarza, a zatem tej, którą zdaje się pełnić od samego początku. Tym samym powieściowe realia przybierają status symulakrum zdolnego do ukazywania się w nieograniczonej liczbie kopii. Powieść Miloša manifestuje więc cechę typową dla dystopii - pojawia się w niej wątek wynoszenia repliki ponad oryginał, podważania statusu rzeczywistości. Tekst Chorwata posiada $\mathrm{i}$ inne cechy charakterystyczne dla wskazanego gatunku.

„Dystopia - zauważa Joanna Jezierska-Haładyj - nawet gdy odsłaniają się jej zasady, nie zagarnia fabuły, mroczna rzeczywistość nieubłaganie towarzyszy bohaterom, ale

${ }^{15}$ Joanna Jezierska-Haładyj wskazuje, że poznanie poprzez pryzmat ograniczonej wiedzy narratora typowe jest np. dla powieści dystopijnej, w której czytelnik „rekonstruuje mroczną rzeczywistość z porozrzucanych, niepokojących sygnałów” (Jeziorska-Haładyj, 2007, s. 169). Analogiczną prawidłowość można zauważyć w omawianej powieści. 
traktują to jako najbardziej naturalną rzecz na świecie. I tu również, jak u Barnesa, nie ma miejsca na bunt czy otwarte kwestionowanie założeń nowego „wspaniałego” świata" (Jeziorska-Haładyj, 2007, s. 175).

Bohaterowie Miloša zgodnie z przytoczoną zasadą przyjmują zastane realia jako ustalone i niezmienne, prezentując całkowity nihilizm. Ta ostatnia przypadłość typowa jest, jak wskazuje Nikola Dedić, dla twórców postmodernistycznych, którzy nie pragną już, jak moderniści, poprawiać świata, a sztukę odczytują jako ironiczny i skrajnie indywidualny akt samozadowolenia (Dedić, 2009, s. 197). Pozwalają sobie oni na relatywizację stosunku do historii i tradycji, wręcz ich alogiczne replikowanie, na nomadyczną wędrówkę po zasobach dorobku literackiego i kulturowego wielu wieków, czego znakomite przykłady można odnaleźć w pracy Miloša. Autor powieści z brawurowym wręcz rozmachem wzbogaca bowiem współczesny krajobraz wyspiarski w typowe dla okresu kreteńskiego elementy sztuki, urozmaica go „pamiątkami” po Dionizosie i nawiązuje do Lukiana i Rabelais'ego, a tym samym funduje czytelnikowi „podróż w hiperrealność” spod znaku Umberto Eco. To wizja rzeczywistości, którą Zygmunt Bauman wyobraża jako kapryśnego gracza, którego poczynania są nieprzewidywalne:

„Rzecz w tym raczej, że coraz bardziej przypomina nam ten świat gracza, tulącego karty do piersi, a coraz mniej prawodawcę czy sędziego, trzymającego się kurczowo prawnego kodeksu. A na dobitek jeszcze w tej grze, w której świat jest graczem, przepisy zdają się zmieniać w toku grania, znikać i pojawiać bez uprzedzenia. W takiej grze nie da się orzec, co jest koniecznością a co przypadkiem, a i samo rozróżnienie traci, prawdę mówiąc, sens. W tej grze są tylko ruchy graczy i liczy się tylko kamienna twarz, chytre wyjście i sprytne rozegranie posiadanej karty" (Bauman, 2013b, s. 153).

Dedić, charakteryzując typ kultury, jaki wyłania się z powieści postmodernistycznych (w moim odczuciu także z powieści Chorwata) jako antyprogresywny, antylinearny i ironiczny, widzi w nim spadkobiercę epoki manieryzmu, w której analogicznie jak w ponowoczesności wyobcowany intelektualista nie rozpoznawał ani swojego obowiązku, ani roli, co skutkowało powstawaniem sztuki „całkowitego oddalenia od świata” (Dedić, 2009, s. 198). I tak jak artysta-manierysta usiłował zburzyć istniejące formy i odnaleźć swój indywidualny rys, tak postmodernista oddaje się subiektywności, własnym przeżyciom i snom, oferując co najwyżej fragmentaryczną wizję świata, w ramach której można wprawdzie dostrzec krytykę totalizujących utopii modernistycznych oraz niewiarę w jakiekolwiek dające nadzieję projekty, ale nic ponadto. Zmienił się sposób, w jaki myślenie utopijne się objawia, z ducha postmodernistyczna 
wydaje się dystopia czy antyutopia, nie widać zatem, co naturalne, optymizmu, który Leszek Kleszcz przypisywał myśli utopijnej (Kleszcz, 1997, s. 160), ale nie widać też celu, jaki te formy utopii miałyby sobie stawiać, celu, o którym pisał i który zapowiadał Michał Mokrzan. Jest raczej tak, jak chce przywoływany przez Joannę Jeziorską-Haładyj Keith Booker: wprawdzie wybitne dwudziestowieczne dystopie bywały przestrogą i wołaniem o opamiętanie - pełniąc w ten sposób funkcję dydaktyczną i zdradzając swoje zaangażowanie w rzeczywistość - tym niemniej współczesne dystopie postmodernistyczne najczęściej powątpiewają w skuteczność własnych interwencji, a często są też własnymi parodiami (Jeziorska-Haładyj, 2007, s. 170), co bez wątpienia dotyczy tekstu Chorwata.

Gdyby w tym momencie spróbować odpowiedzieć na pytanie postawione przez Bogdana Banasika, poprzez które próbuje on dociec sensu sięgania po utopię, odpowiedź ta nie byłaby optymistyczna. Modernistyczna utopia Novaka jawi się bowiem jako przejaw resentymentu, próba rekompensaty nie dość zadowalającej rzeczywistości, a postmodernistyczna dystopia Miloša, choć nie jest nosicielką tej przypadłości, nie posiada też jakichkolwiek znamion pozytywnego projektu. Swoim tekstem autor potwierdza tylko trwanie ludzkości w stadium zanurzenia w myśleniu utopijnym, niemożność wyjścia poza utopijny dyskurs, choć jego przydatność, przynajmniej chwilowo, wydaje się nikła.

Sytuację tę "ratuje” tekst ostatniego z omawianych tu autorów - Vodič po otoku Senka Karuzy, zbiór krótkich opowiadań, w których grupowy narrator, przemawiając $w$ imieniu rdzennych mieszkańców wysp, przedstawia nieturystyczne realia bytowania na nich. Paradoksem jest jednak fakt, że książka ta nie wpisuje się w tradycyjnie rozumiany gatunek utopii, że to jej wariant na miarę po-ponowoczesności, utopia czasów, w których, jak zauważa Nikola Dedić - powołując się na działalność i myśl Johna Cage’a, jednego z najbardziej znanych kompozytorów muzyki dwudziestowiecznej i jednocześnie jednej z najbardziej kontrowersyjnych postaci współczesnej kultury - kryteria oceny sztuki nie są estetyczne, lecz społeczne. Jeśli w ogóle można nazwać pracę Karuzy utopijną, to tylko jako taki przejaw sztuki, która jest praktyką definiowania wyizolowanych utopijnych przestrzeni krytyki aktualnego społecznego porządku (Dedić, 2009, s. 272). Przy czym obie one - praktyka i krytyka - również mają charakter paradoksalny, ponieważ dokonują się niejako mimochodem, przy okazji, nie są celem samym w sobie. Wydźwięk książki Karuzy, na której kartach mieszkaniec wyspy, najpewniej sam autor, prostym językiem opowiada o własnej codzienności, zwyczajności bytowania lokalnej wspólnoty, jej rytuałach, pragnieniach i niepokojach, o samotności i chwilach beztroskiego szczęścia, współbrzmi bowiem z najsłynniejszym 
tekstem Johna Cage'a Lecture on nothing: „I have nothing to say and I am saying it. [...] Most speeches are full of ideas. This one doesn't have to have any. But at any moment an idea may come along. Then we may enjoy it" (Cage, 1959, s. 109, 113). Analogiczny sens tego $z$ ducha Heideggerowskiego wywodu ${ }^{16}$, który pod pojęciem idei przywodzi na myśl pojęcie prawdy aleteicznej, prawdy samego bycia, tej, która, jak przypomina Hanna Buczyńska-Garewicz, pojawia się przypadkowo, w prześwitach polnych ścieżek i leśnych dróg, które z założenia prowadzą donikąd (Buczyńska-Garewicz, 2008), odnaleźć można w poszczególnych partiach pracy Karuzy, gdzie ukazana w powszedniej krzątaninie jednostka, skoncentrowana na rzeczach małych i przyziemnych, odkrywa w nich znaczenie godnego bytowania: „U tom minimalnom prostoru, u kojem se jedino možemo okretati oko sebe, shvaćamo koliko nam malo treba, jer sve je nadohvat ruke" (Karuza, 2007, s. 224) Egzystencja ta niekiedy ma charakter radosny i błogi, zwłaszcza gdy opowiadacz rozwodzi się nad miejscowymi rarytasami: „Slažemo napokon ribu, zalijevamo je maslinovim uljem, ne štedimo, neka svi vide da je sada, ovdje i ovakav život najbolji..." (Karuza, 2007, s. 224) ${ }^{18}$. Innymi razy jawi się natomiast jako wymagająca i trudna, ponieważ wpisane jest w nią poczucie pustki:

„sve teže podnosimo samoću. Gledamo kamene kuće i zatvorene škure, sjećamo se kad su bile otvorene i žive, zamišljamo kolika bi to zbrka bila da su svi ostali i koliko bi trebalo proširiti ovaj naš Dom. (...) Nestrpljivi smo i otključavamo vrata kazališta, ulazimo u tu hladnoću praznine i sjedamo za naš drveni stol. Miješamo karte iako znamo da danas neće biti igre" (Karuza, 2007, s. 273) ${ }^{19}$.

W tych i tym podobnych miniaturach narrator tekstu Chorwata poprzez aktywowanie warunkowego trybu kultury, o który upominała się Anna Zeidler-Janiszewska ${ }^{20}$, zwrot ku ponownemu doświadczaniu i zbieractwu

${ }^{16}$ Na temat związków myśli Cage’a z Heideggerem zob. Luty (2009, s. 98-99).

17 „Na tej minimalnej przestrzeni, w której możemy się jedynie okręcać wokół siebie, zaczynamy rozumieć, jak mało nam trzeba, bo wszystko jest na wyciągnięcie ręki” (Karuza, 2008, s. 43).

18 „Układamy w końcu rybę na półmisku, skrapiamy ją oliwą z oliwek, nie oszczędzamy, niech wszyscy widzą, że tu i teraz, i właśnie takie życie jest najlepsze...” (Karuza, 2008, s. 18).

19 „coraz gorzej znosimy samotność. Patrzymy na kamienne domy i zamknięte drewniane okiennice, pamiętamy, jak były otwarte i pełne życia, wyobrażamy sobie to zamieszanie, gdyby wszyscy tu zostali i o ile trzeba byłoby powiększyć ten nasz Dom Kultury. (...) Jesteśmy niecierpliwi i otwieramy drzwi teatru, wchodzimy do tej chłodnej pustki i siadamy za naszym drewnianym stołem. Tasujemy karty, choć wiemy, że dziś nie będzie gry” (Karuza, 2008, s. 67).

${ }^{20}$ Anna Zeidler-Janiszewska odróżnia orzekający tryb kultury od trybu warunkowego, uznając, że ten pierwszy, który zdominował nowoczesność, polega na „profesjonalizacji” ludz- 
spod znaku Manfreda Sommera ${ }^{21}$, gromadzeniu doświadczeń, uważnej acz niezobowiązującej obserwacji, ku przechadzce po nieszczególnie ważnych zakątkach wyspy - przechadzce, która, jak zaznaczał Stefan Symiotuk (1997, s. 107), tylko z pozoru wydaje się błaha - w przypadkowym „dzianiu się” odkrywa istotę ludzkiej egzystencji, sens dobrego (co nie znaczy jednak - zupełnie beztroskiego) życia. Takiego, które toczy się swoim powolnym tempem i w którym człowiek ma czas na poranną kawę ze znajomymi, sentymentalną wędrówkę na strych pełen znajomych rupieci, baczne obserwowanie kota, pichcenie i smakowanie lokalnych smakołyków. W tym obrazie, chciałoby się powiedzieć, normalności, przynależności do rodzimych stron, dopatrzyć się można zapowiedzianej utopijnej przestrzeni, która - skontrastowana na kartach książki Karuzy z wizją wiecznie niestałego terytorium postmodernistycznego turysty (autor z nutą drwiny opisuje gorączkową bieganinę przybysza raz szukającego stereotypowo idyllicznych krajobrazów, kiedy indziej „dzikiej” natury i „robinsonowskiego" spokoju) - urasta do krytyki porządku, $\mathrm{w}$ jakim ten funkcjonuje, krytyki czasów ponowoczesnych i przynależnych im wartości (lub ich braku).

Trudno powiedzieć, czy zaprezentowana w książce wizja to nowy typ utopii i czy literatura chorwacka może wyznaczać (czy współwyznaczać) nowe tendencje w kulturze Zachodu. Nie wiadomo również, czy protagonista Vodiča... to kandydat na bohatera po-ponowoczesności, który stanie niegdyś obok Baumanowskiego wędrowca i turysty, oraz czy już stoimy u jej progu. Myślę jednak, że gdyby tak było, wkroczylibyśmy w „nowe czasy” z nadzieją, która nie musiałaby być naiwna.

kiego doświadczenia, na nadawaniu mu wymiaru poznawczo-praktycznego. Tryb warunkowy, znany w społecznościach zbierackich, zakładał istnienie doświadczenia, które nie było celowym działaniem. Protagonista tekstu Karuzy niejako powraca do tego rodzaju doświadczenia (Zeidler-Janiszewska, 2006, s. 12-13).

${ }^{21}$ Manfred Sommer tak oto opisuje zbieranie doświadczenia, charakterystyczne dla warunkowego trybu kultury (o którym pisze Zeidler-Janiszewska): „Szukano zatem z ciekawości, ale bez planu; świadomie, ale przypadkowo; okazjonalnie i niesystematycznie - jednym słowem: «dziko». Jeśli tylko rozpasane spojrzenie szczęśliwie padnie na coś rzadkiego i podniecającego, to kierownictwo przejmuje sama rzecz: To ona natychmiast przyciąga spojrzenie i od tej chwili kieruje nim. Jeśli ktoś patrzy w ten sposób, to jego spostrzeżenie nie jest kierowanym przez niego działaniem; jest on tylko miejscem, w którym się ono dokonuje. Spostrzeżenie dzieje się i jest czymś, co jemu się dzieje" (Sommer, 2003, s. 331). Analogicznie upływa wyspiarska egzystencja bohatera Karuzy, który jest mocno przy rzeczach i w które po Heideggerowsku się wsłuchuje. 


\section{BIBLIOGRAFIA}

Banasik, B. (2010). O bohaterach i rajach. Utopia i optymizm jako wyznaczniki kultury Zachodu. W: T. Sieczkowski \& D. Misztal (Red.), Utopia - wczoraj i dziś (s. 23-42). Toruń: Wydawnictwo Adam Marszałek.

Bauman, Z. (2013a). O parweniuszu i pariasie, czyli o bohaterach i ofiarach nowoczesności. W: Z. Bauman, Ponowoczesność jako źródło cierpień (s. 123-143). Warszawa: Wydawnictwo Sic!

Bauman, Z. (2013b). O turystach i włóczęgach, czyli o bohaterach i ofiarach ponowoczesności. W: Z. Bauman, Ponowoczesność jako źródło cierpień (s. 145-166). Warszawa: Wydawnictwo Sic!

Benjamin, W. (1996). O pojęciu historii. Tłum. K. Krzemieniowa. W: W. Benjamin, Anioł historii. Eseje, szkice, fragmenty (s. 413-425). Tłum. K. Krzemieniowa, H. Orłowski, \& J. Sikorski. Poznań: Wydawnictwo Poznańskie.

Boguska, A. (2009). Chorwackie Wyspy Szczęśliwe. Od mitologizacji przestrzeni do fenomenologii miejsca. Przeglad Humanistyczny, 4(415), 79-87.

Boguska, A. (2011). Mistyfikacje chorwackiego raju. Rzecz o prozie wyspiarskiej Senka Karuzy. W: Истина, мистификация, лъжа в славянските езици, литератури и култури (s. 404-411). София: ЛЕКТУРА.

Boguska, A. (2012). Autentyczność poszukiwana. O czytaniu tożsamości chorwackich wyspiarzy poprzez literackie obrazy wysp. W: E. Gołachowska \& A. Zielińska (Red.), Konstrukcje i destrukcje tożsamości. Tożsamość wobec wielojęzyczności (s. 365-380). Warszawa: Slawistyczny Ośrodek Wydawniczy.

Brešić, V. (2004). Slavonska književnost. Prilog hrvatskoj književnoj topografiji. W: S. Botica (Red.), Zbornik Zagrebačke Slavističke Škole 2003 (s. 75-85). Zagreb: Filozofski fakultet u Zagrebu.

Brešić, V. (2005). Slavonska poetika zemlje. Vijenac, (288). Pobrano z http://www.matica.hr/ Vijenac/vijenac288.nsf/AllWebDocs/Vinko.html

Buczyńska-Garewicz, H. (2008). Aletheia. W: H. Buczyńska-Garewicz, Prawda i złudzenie. Eseje o myśleniu (s. 155-204). Kraków: Universitas.

Cage, J. (1959). Lecture on nothing. Incontri Musicali, 3, 109-126.

Curtius, E. R. (2005). Krajobraz idealny. W: E. R. Curtius, Literatura europejska i łacińskie średniowiecze (s. 191-209). Tłum. A. Borowski. Kraków: Universitas.

Czapik-Lityńska, B. (2005). „Ja jestem“ - myślący podmiot na scenie pisma i na scenie świata. W: B. Czapik-Lityńska (Red.), Literatury słowiańskie po roku 1989. Nowe zjawiska, tendencje, perspektywy (T. 3, Podmiotowość, s. 223-233). Warszawa: Dom Wydawniczy ELIPSA.

Dąbrowska-Partyka, M. (2005). Postmodernistyczna twarz postkomunizmu, czyli jako zostać prawdziwym Chorwatem. W: H. Janaszek-Ivaničkova (Red.), Literatury słowiańskie po roku 1989. Nowe zjawiska, tendencje, perspektywy (T. 2, Transformacja, s. 214-221). Warszawa: Dom Wydawniczy ELIPSA.

Dedić, N. (2009). Utopijski prostori umetnosti i teorije posle 1960. Beograd: ATOČA.

Duda, D. (2005). Literatura chorwacka w neokapitalistycznej artykulacji. W: H. Janaszek-Ivaničkova (Red.), Literatury słowiańskie po roku 1989. Nowe zjawiska, tendencje, perspektywy (T. 1, Transformacja, s. 230-237). Warszawa: Dom Wydawniczy ELIPSA. 
Dyras, M. (1999). Figura losu chorwackiego w cyklu „vukovarskim” Pavao Pavličicia. W: J. Kornhauser (Red.), Przemiany w świadomości i kulturze duchowej narodów Jugosławii po 1991 roku (s. 161-173). Kraków: Wydawnictwo Uniwersytetu Jagiellońskiego.

Dyras, M. (2002). Strategie odzyskiwania utraconej tożsamości. Chorwacka „powieść o historii”. W: B. Zieliński (Red.), Narodowy i ponadnarodowy model kultury. Europa Środkowa i Półwysep Bałkański (s. 113-119). Poznań: Wydawnictwo Naukowe UAM.

Dyras, M. (2009). Re-inkarnacje narodu. Chorwackie narracje tożsamościowe w latach dziewięćdziesiątych XX wieku. Kraków: Wydawnictwo Uniwersytetu Jagiellońskiego.

Gillis, J. (2004). Islands of the mind. How the Human Imagination Created the Atlantic World. New York: Palgrave Macmillan.

Gosk, H. (2007). Od modelu rzeczywistości idealnej do symulakrum. Utopii socrealistycznej życie po życiu. W: E. Paczoska \& J. Sadowski (Red.), Homo utopicus, terra utopica. O utopii i jej lekturach (T. 2, s. 139-151). Warszawa: Studium Europy Wschodniej Uniwersytetu Warszawskiego.

Jawoszek, A. (2009). Listy o kraju, którego nie ma (Amerykański fikcjonarz, Muzeum bezwarunkowej kapitulacji). W: C. Juda (Red.), Słowiańskie diaspory. Studia o literaturze emigracyjnej (s. 149-157). Kraków: Wydawnictwo Uniwersytetu Jagiellońskiego.

Jeziorska-Haładyj, J. (2007). Poetyka współczesnej powieści dystopijnej (na przykładach z najnowszej prozy brytyjskiej). W: E. Paczoska \& J. Sadowski (Red.), Homo utopicus, terra utopica. O utopii i jej lekturach (T. 2, s. 167-177). Warszawa: Studium Europy Wschodniej Uniwersytetu Warszawskiego.

Karuza, S. (2007). Vodič po otoku. W: S. Karuza, Teško mi je reći-sabrane priče (s. 213-313). Zagreb: Profil.

Karuza, S. (2008). Przewodnik po wyspie. Tłum. B. Kramar. Warszawa: Czytelnik.

Kleszcz, L. (1997). Filozofia i utopia. Platon, Biblia, Nietzsche. Wrocław: Wydawnictwo Uniwersytetu Wrocławskiego.

Kornhauser, J. (1999). Chorwacka poezja martyrologiczna po 1991 roku i stereotypy narodowe. W: J. Kornhauser (Red.), Przemiany w świadomości i kulturze duchowej narodów Jugosławii po 1991 roku (s. 153-160). Kraków: Wydawnictwo Uniwersytetu Jagiellońskiego.

Kornhauser, J. (2001). Poezja „krugovców”. Rozpoznanie wstępne. W: W. Lubaś \& M. Balowski (Red.), Studia nad współczesnymi językami i literaturami południowo- $i$ zachodniosłowiańskimi (s. 11-18). Opole: Wydawnictwo Uniwersytetu Opolskiego.

Kornhauser, J. (2003). Polscy „oniryści”, chorwaccy „borgesowcy” i serbscy „charmsowcy” - fantastyczny wariant postmodernizmu (funkcja procesu historycznoliterackiego). W: A. Dudek (Red.), Z polskich studiów slawistycznych. Literaturoznawstwo (s. 125-132). Warszawa: Wydawnictwo Naukowe PWN.

Kornhauser, J. (2005). Reinterpretacja tradycji w postjugosłowiańskich pracach historycznoliterackich. W: M. Dąbrowska-Partyka (Red.), W poszukiwaniu nowego kanonu. reinterpretacje tradycji kulturalnej w krajach postjugosłowiańskich po 1995 roku (s. 423-472). Kraków: Wydawnictwo Uniwersytetu Jagiellońskiego.

Luty, J. (2009). Puste słowa Johna Cage'a. Dyskurs. Pismo Naukowo-Artystyczne ASP we Wrocławiu, 9, 95-113.

Małczak, L. (2004). Wiatr w literaturze chorwackiej. Ofigurze literackiej wiatru u XIX-i XX-wiecznym piśmiennictwie chorwackim strefy śródziemnomorskiej. Poznań: Wydawnictwo Naukowe UAM. 
Małczak, L. (2005a). Miljenko Jergović - ponowoczesny apatryda. W: B. Czapik-Lityńska \& M. Buczek (Red.), Z dziejów podmiotu i podmiotowości w literaturach słowiańskich XX w. (s. 246-258). Katowice: Wydawnictwo Uniwersytetu Śląskiego.

Małczak, L. (2005b). Przestrzenne konteksty chorwackiego literaturoznawstwa. W: L. Miodyński (Red.), Cywilizacja - przestrzeń - teksty. Słowiańska topografia kulturowa w języku i literaturze (s. 47-59). Katowice: Wydawnictwo Uniwersytetu Śląskiego.

Mokrzan, M. (2006). Postmodernizm - zmierzch czy afirmacja utopii? W: E. Paczoska \& J. Sadowski (Red.), Homo utopicus, terra utopica. O utopii i jej lekturach (T. 1, s. 65-77). Warszawa: Studium Europy Wschodniej Uniwersytetu Warszawskiego.

Nemec, K. (2006). Hrvatska inzularna proza. HUM - časopis Filozofskog fakulteta Sveučilišta u Mostaru, 1, 9-30.

Novak, S. (1969). Izgubljeni zavičaj. W: S. Novak, Izgubljeni zavičaj. Dolutali metak (s. 9-80). Zagreb: Izdavačko poduzeće Zora.

Novak, S. (1990). Już nie u siebie i 9 opowiadań. Tłum. J. Chmielewski, D. Cirlić-Straszyńska, \& A. Dukanović. Warszawa: Państwowy Instytut Wydawniczy.

Panofsky, E. (1971). Et in Arcadia ego. Poussin i tradycja elegijna. Tłum. A. Morawińska. W: E. Panofsky, Studia z historii sztuki (s. 324-342). Tłum. K. Kamińska i in. Warszawa: Państwowy Instytut Wydawniczy.

Pavličić, P. (2004). Hrvatska književnost sjevera i juga. W: S. Botica (Red.), Zbornik Zagrebačke Slavističke Škole 2003 (s. 115-119). Zagreb: Filozofski fakultet u Zagrebu, Zagrebačka slavistička škola, Hrvatski seminar za strane slaviste.

Pieniążek-Marković, K. (2005). Ekspresje (nie)podmiotowości i (nie)tożsamości w najnowszej poezji chorwackiej. W: B. Czapik-Lityńska (Red.), Literatury słowiańskie po roku 1989. Nowe zjawiska, tendencje, perspektywy (T. 3, Podmiotowość, s. 212-222). Warszawa: Dom Wydawniczy ELIPSA.

Pieniążek-Marković, K. (2011). „Ja” - człowiek i świat w najnowszej poezji chorwackiej (1990-2010). Poznań: Wydawnictwo Naukowe UAM.

Sommer, M. (2003). Zbieranie. Próba filozoficznego ujęcia. Tłum. J. Merecki. Warszawa: Oficyna Naukowa.

Symiotuk, S. (1997). „Przechadzka” jako czynność filozoficzna. W: S. Symiotuk, Filozofia i genius loci (s. 105-123). Warszawa: IK.

Szacki, J. (2000). Spotkania z utopia. Warszawa: Wydawnictwo „Sic!”.

Wesseling, E. (1997). Historical Fiction. Utopia in History. W: H. Bertens \& D. W. Fokkema (Red.), International Postmodernism: Theory and Literary Practice (s. 203-211). Amsterdam, Philadelphia: John Benjamins Publishing.

Wojciechowski, P. (2007). Modernistyczny homo utopicus w „Mirandzie” Antoniego Langego. W: E. Paczoska \& J. Sadowski (Red.), Homo utopicus, terra utopica. O utopii i jej lekturach (T. 2, s. 105-116). Warszawa: Studium Europy Wschodniej Uniwersytetu Warszawskiego.

Wołek-San Sebastian, K. (2009). Chorwaci, emigracja, mit. W: C. Juda (Red.), Słowiańskie diaspory. Studia o literaturze emigracyjnej (s. 159-166). Kraków: Wydawnictwo Uniwersytetu Jagiellońskiego.

Zeidler-Janiszewska, A. (2006). Progi i granice doświadczenia (w) nowoczesności. Teksty Drugie, (3), 12-13. 


\section{BIBLIOGRAPHY}

\section{(TRANSLITERATION)}

Banasik, B. (2010). O bohaterach i rajach. Utopia i optymizm jako wyznaczniki kultury Zachodu. In: T. Sieczkowski \& D. Misztal (Eds.), Utopia - wczoraj i dziś (p. 23-42). Toruń: Wydawnictwo Adam Marszałek.

Bauman, Z. (2013a). O parweniuszu i pariasie, czyli o bohaterach i ofiarach nowoczesności. In: Z. Bauman, Ponowoczesność jako źródło cierpień (p. 123-143). Warszawa: Wydawnictwo Sic!

Bauman, Z. (2013b). O turystach i włóczęgach, czyli o bohaterach i ofiarach ponowoczesności. In: Z. Bauman, Ponowoczesność jako źródło cierpień (p. 145-166). Warszawa: Wydawnictwo Sic!

Benjamin, W. (1996). O pojęciu historii. Trans. K. Krzemieniowa. In: W. Benjamin, Anioł historii. Eseje, szkice, fragmenty (p. 413-425). Trans. K. Krzemieniowa, H. Orłowski, \& J. Sikorski. Poznań: Wydawnictwo Poznańskie.

Boguska, A. (2009). Chorwackie Wyspy Szczęśliwe. Od mitologizacji przestrzeni do fenomenologii miejsca. Przegląd Humanistyczny, 4(415), 79-87.

Boguska, A. (2011). Mistyfikacje chorwackiego raju. Rzecz o prozie wyspiarskiej Senka Karuzy. In: Istina, mistifikatsiia, lŭzha v slavianskite ezitsi, literaturi i kulturi (p. 404-411). Sofiia: LEKTURA.

Boguska, A. (2012). Autentyczność poszukiwana. O czytaniu tożsamości chorwackich wyspiarzy poprzez literackie obrazy wysp. In: E. Gołachowska \& A. Zielińska (Eds.), Konstrukcje i destrukcje tożsamości. Tożsamość wobec wielojęzyczności (p. 365-380). Warszawa: Slawistyczny Ośrodek Wydawniczy.

Brešić, V. (2004). Slavonska književnost. Prilog hrvatskoj književnoj topografiji. In: S. Botica (Ed.), Zbornik Zagrebačke Slavističke Škole 2003 (p. 75-85). Zagreb: Filozofski fakultet u Zagrebu.

Brešić, V. (2005). Slavonska poetika zemlje. Vijenac, (288). Retrieved from http://www.matica. $\mathrm{hr} /$ Vijenac/vijenac288.nsf/AllWebDocs/Vinko.html

Buczyńska-Garewicz, H. (2008). Aletheia. In: H. Buczyńska-Garewicz, Prawda i złudzenie. Eseje o myśleniu (p. 155-204). Kraków: Universitas.

Cage, J. (1959). Lecture on nothing. Incontri Musicali, 3, 109-126.

Curtius, E. R. (2005). Krajobraz idealny. In: E. R. Curtius, Literatura europejska i łacińskie średniowiecze (p. 191-209). Trans. A. Borowski. Kraków: Universitas.

Czapik-Lityńska, B. (2005). „Ja jestem“ - myślący podmiot na scenie pisma i na scenie świata. In: B. Czapik-Lityńska (Ed.), Literatury słowiańskie po roku 1989. Nowe zjawiska, tendencje, perspektywy (Vol. 3, Podmiotowość, p. 223-233). Warszawa: Dom Wydawniczy ELIPSA.

Dąbrowska-Partyka, M. (2005). Postmodernistyczna twarz postkomunizmu, czyli jako zostać prawdziwym Chorwatem. In: H. Janaszek-Ivaničkova (Ed.), Literatury słowiańskie po roku 1989. Nowe zjawiska, tendencje, perspektywy (Vol. 2, Transformacja, p. 214-221). Warszawa: Dom Wydawniczy ELIPSA.

Dedić, N. (2009). Utopijski prostori umetnosti i teorije posle 1960. Beograd: ATOČA.

Duda, D. (2005). Literatura chorwacka w neokapitalistycznej artykulacji. In: H. Janaszek-Ivaničkova (Ed.), Literatury słowiańskie po roku 1989. Nowe zjawiska, tendencje, perspektywy (Vol. 1, Transformacja, p. 230-237). Warszawa: Dom Wydawniczy ELIPSA. 
Dyras, M. (1999). Figura losu chorwackiego w cyklu „vukovarskim” Pavao Pavličicia. In: J. Kornhauser (Ed.), Przemiany w świadomości i kulturze duchowej narodów Jugosławii po 1991 roku (p. 161-173). Kraków: Wydawnictwo Uniwersytetu Jagiellońskiego.

Dyras, M. (2002). Strategie odzyskiwania utraconej tożsamości. Chorwacka „powieść o historii”. In: B. Zieliński (Ed.), Narodowy i ponadnarodowy model kultury. Europa Środkowa i Półwysep Bałkański (p. 113-119). Poznań: Wydawnictwo Naukowe UAM.

Dyras, M. (2009). Re-inkarnacje narodu. Chorwackie narracje tożsamościowe w latach dziewięćdziesiątych XX wieku. Kraków: Wydawnictwo Uniwersytetu Jagiellońskiego.

Gillis, J. (2004). Islands of the mind. How the Human Imagination Created the Atlantic World. New York: Palgrave Macmillan.

Gosk, H. (2007). Od modelu rzeczywistości idealnej do symulakrum. Utopii socrealistycznej życie po życiu. In: E. Paczoska \& J. Sadowski (Eds.), Homo utopicus, terra utopica. O utopii i jej lekturach (Vol.2, p. 139-151). Warszawa: Studium Europy Wschodniej Uniwersytetu Warszawskiego.

Jawoszek, A. (2009). Listy o kraju, którego nie ma (Amerykański fikcjonarz, Muzeum bezwarunkowej kapitulacji). In: C. Juda (Ed.), Słowiańskie diaspory. Studia o literaturze emigracyjnej (p. 149-157). Kraków: Wydawnictwo Uniwersytetu Jagiellońskiego.

Jeziorska-Haładyj, J. (2007). Poetyka współczesnej powieści dystopijnej (na przykładach z najnowszej prozy brytyjskiej). In: E. Paczoska \& J. Sadowski (Eds.), Homo utopicus, terra utopica. O utopii i jej lekturach (Vol.2, p. 167-177). Warszawa: Studium Europy Wschodniej Uniwersytetu Warszawskiego.

Karuza, S. (2007). Vodič po otoku. In: S. Karuza, Teško mi je reći-sabrane priče (p. 213-313). Zagreb: Profil.

Karuza, S. (2008). Przewodnik po wyspie. Trans. B. Kramar. Warszawa: Czytelnik.

Kleszcz, L. (1997). Filozofia i utopia. Platon, Biblia, Nietzsche. Wrocław: Wydawnictwo Uniwersytetu Wrocławskiego.

Kornhauser, J. (1999). Chorwacka poezja martyrologiczna po 1991 roku i stereotypy narodowe. In: J. Kornhauser (Ed.), Przemiany w świadomości i kulturze duchowej narodów Jugosławii po 1991 roku (p. 153-160). Kraków: Wydawnictwo Uniwersytetu Jagiellońskiego.

Kornhauser, J. (2001). Poezja „krugovców”. Rozpoznanie wstępne. In: W. Lubaś \& M. Balowski (Eds.), Studia nad współczesnymi językami i literaturami południowo- i zachodniosłowiańskimi (p. 11-18). Opole: Wydawnictwo Uniwersytetu Opolskiego.

Kornhauser, J. (2003). Polscy „oniryści”, chorwaccy „borgesowcy” i serbscy „charmsowcy” - fantastyczny wariant postmodernizmu (funkcja procesu historycznoliterackiego). In: A. Dudek (Ed.), Z polskich studiów slawistycznych. Literaturoznawstwo (p. 125-132). Warszawa: Wydawnictwo Naukowe PWN.

Kornhauser, J. (2005). Reinterpretacja tradycji w postjugosłowiańskich pracach historycznoliterackich. In: M. Dąbrowska-Partyka (Ed.), W poszukiwaniu nowego kanonu. reinterpretacje tradycji kulturalnej w krajach postjugosłowiańskich po 1995 roku (p. 423-472). Kraków: Wydawnictwo Uniwersytetu Jagiellońskiego.

Luty, J. (2009). Puste słowa Johna Cage'a. Dyskurs. Pismo Naukowo-Artystyczne ASP we Wrocławiu, 9, 95-113.

Małczak, L. (2004). Wiatr w literaturze chorwackiej. O figurze literackiej wiatru u XIX-i XX-wiecznym piśmiennictwie chorwackim strefy śródziemnomorskiej. Poznań: Wydawnictwo Naukowe UAM. 
Małczak, L. (2005a). Miljenko Jergović - ponowoczesny apatryda. In: B. Czapik-Lityńska \& M. Buczek (Eds.), Z dziejów podmiotu i podmiotowośći w literaturach słowiańskich XX $w$. (p. 246-258). Katowice: Wydawnictwo Uniwersytetu Śląskiego.

Małczak, L. (2005b). Przestrzenne konteksty chorwackiego literaturoznawstwa. In: L. Miodyński (Ed.), Cywilizacja - przestrzeń - teksty. Słowiańska topografia kulturowa w języku i literaturze (p. 47-59). Katowice: Wydawnictwo Uniwersytetu Śląskiego.

Mokrzan, M. (2006). Postmodernizm - zmierzch czy afirmacja utopii? In: E. Paczoska \& J. Sadowski (Ed.), Homo utopicus, terra utopica. O utopii i jej lekturach (Vol. 1, p. 65-77). Warszawa: Studium Europy Wschodniej Uniwersytetu Warszawskiego.

Nemec, K. (2006). Hrvatska inzularna proza. HUM - časopis Filozofskog fakulteta Sveučilišta u Mostaru, 1, 9-30.

Novak, S. (1969). Izgubljeni zavičaj. In: S. Novak, Izgubljeni zavičaj. Dolutali metak (p. 9-80). Zagreb: Izdavačko poduzeće Zora.

Novak, S. (1990). Już nie u siebie i 9 opowiadań. Trans. J. Chmielewski, D. Cirlić-Straszyńska \& A. Dukanović. Warszawa: Państwowy Instytut Wydawniczy.

Panofsky, E. (1971). Et in Arcadia ego. Poussin i tradycja elegijna. Trans. A. Morawińska. In: E. Panofsky, Studia z historii sztuki (s. 324-342). Trans. K. Kamińska et al. Warszawa: Państwowy Instytut Wydawniczy.

Pavličić, P. (2004). Hrvatska književnost sjevera i juga. In: S. Botica (Ed.), Zbornik Zagrebačke Slavističke Škole 2003 (p. 115-119). Zagreb: Filozofski fakultet u Zagrebu, Zagrebačka slavistička škola, Hrvatski seminar za strane slaviste.

Pieniążek-Marković, K. (2005). Ekspresje (nie)podmiotowości i (nie)tożsamości w najnowszej poezji chorwackiej. In: B. Czapik-Lityńska (Ed.), Literatury słowiańskie po roku 1989. Nowe zjawiska, tendencje, perspektywy (Vol.3, Podmiotowość, p. 212-222). Warszawa: Dom Wydawniczy ELIPSA.

Pieniążek-Marković, K. (2011). „Ja” - człowiek i świat w najnowszej poezji chorwackiej (1990-2010). Poznań: Wydawnictwo Naukowe UAM.

Sommer, M. (2003). Zbieranie. Próba filozoficznego ujęcia. Trans. J. Merecki. Warszawa: Oficyna Naukowa.

Symiotuk, S. (1997). „Przechadzka” jako czynność filozoficzna. In: S. Symiotuk, Filozofia i genius loci (p. 105-123). Warszawa: IK.

Szacki, J. (2000). Spotkania z utopia. Warszawa: Wydawnictwo „Sic!”.

Wesseling, E. (1997). Historical Fiction. Utopia in History. In: H. Bertens \& D. W. Fokkema (Eds.), International Postmodernism: Theory and Literary Practice (p. 203-211). Amsterdam, Philadelphia: John Benjamins Publishing.

Wojciechowski, P. (2007). Modernistyczny homo utopicus w „Mirandzie” Antoniego Langego. In: E. Paczoska \& J. Sadowski (Eds.), Homo utopicus, terra utopica. O utopii i jej lekturach (Vol. 2, p. 105-116). Warszawa: Studium Europy Wschodniej Uniwersytetu Warszawskiego.

Wołek-San Sebastian, K. (2009). Chorwaci, emigracja, mit. In: C. Juda (Ed.), Słowiańskie diaspory. Studia o literaturze emigracyjnej (p. 159-166). Kraków: Wydawnictwo Uniwersytetu Jagiellońskiego.

Zeidler-Janiszewska, A. (2006). Progi i granice doświadczenia (w) nowoczesności. Teksty Drugie, (3), 12-13. 


\section{Przemiany utopii w chorwackiej prozie insularnej drugiej połowy XX i początku XXI wieku na wybranych przykładach}

Artykuł jest próbą pokazania innego sposobu prezentowania najnowszej literatury chorwackiej aniżeli poprzez takie tematy jak problematyka narodowej tradycji kraju, patriotyzm, postkomunizm, kwestie tożsamości i emigracji, co wydaje się najbardziej popularną tendencją wśród polskich badaczy. Autor artykułu, wpisując swoje badanie w nurt regionalistyczny, omawia chorwacką prozę insularną poprzez kategorię utopii. Izgubljeni zavičaj Slobodana Novaka widzi jako przykład utopii modernistycznej, Otok snova Damira Miloša interpretuje jako postmodernistyczną dystopię, zaś Vodič po otoku Senka Karuzy postrzega jako wizję nowego rodzaju utopii post-postmodernistycznej.

Słowa kluczowe: utopia; dystopia; chorwacka proza insularna

\section{Transformations of Utopia in the Croatian Insular Prose of the Second Half of $20^{\text {th }}$ and the First Half of the $21^{\text {st }}$ Centuries Based on Examples}

The article is an attempt to show a different means of presenting the newest Croatian literature than through topics such as the problem of the country's national tradition, patriotism, post-communism, and issues of identity and emigration, which seems to be the most popular tendency among Polish researchers. Placing her research in the regionalistic stream, the author of the article discusses Croatian insular prose through the category of utopia. She sees The lost homeland [Izgubljeni zavičaj] by Slobodan Novak as an example of modern utopia, interprets The Island of Dreams [Otok snova] by Damir Miloš as a postmodern dystopia and perceives A Guide Across the Island [Vodič po otoku] by Senko Karuza as a vision of a new, post-postmodern type of utopia.

Keywords: utopia; dystopia; Croatian insular prose 


\section{Notka o autorze}

Anna Boguska - kroatystka, literaturoznawczyni, doktor nauk humanistycznych w zakresie kulturoznawstwa (rozprawa nt. Literackie dystopie. Przypadek chorwacki przygotowywana jest do druku). Absolwentka Instytutu Slawistyki Zachodniej i Południowej UW oraz studiów doktoranckich na Wydziale Polonistyki UW. Pracuje w Instytucie Slawistyki PAN oraz Studium Europy Wschodniej na Wydziale Orientalistycznym UW. Prowadzi badania nad najnowszą prozą chorwacką. Publikuje w czasopismach i tomach zbiorowych, m.in.: Chorwackie Wyspy Szczęśliwe. Od mitologizacji przestrzeni do fenomenologii miejsca („Przegląd Humanistyczny” 2009, nr 4), Autentyczność poszukiwana. O czytaniu tożsamości chorwackich wyspiarzy poprzez literackie obrazy wysp (2012). 